\title{
Wood Ash Fertilization on Structural Characteristics and Chlorophyll Index of Tropical Forage Grasses
}

\author{
Edna Maria Bonfim-Silva*, Claudia Cardoso dos Santos, Tonny José Araújo da Silva \\ Department of Agricultural and Environmental Engineering, Institute of Agricultural Sciences and Technology, \\ Federal University of Mato Grosso, Rondonópolis, Brazil \\ Email: embonfim@hotmail.com
}

Received 6 May 2015; accepted 6 June 2015; published 9 June 2015

Copyright $(2015$ by authors and Scientific Research Publishing Inc.

This work is licensed under the Creative Commons Attribution International License (CC BY). http://creativecommons.org/licenses/by/4.0/

(c) (7) Open Access

\section{Abstract}

The appropriate nutrient supply via fertilization is essential for an adequate plant growth and development. The objective of this study was to evaluate the structural characteristics and chlorophyll index of Marandu and Xaraes grasses fertilized with wood ash. The experiment was conducted in a greenhouse; the experimental design was entirely randomized, with 12 treatments and six replications arranged in a $2 \times 6$ factorial scheme: two forage grasses (Marandu and Xaraes) and six wood ash doses $\left(0 ; 3 ; 6 ; 9 ; 12\right.$; and $\left.15 \mathrm{~g} \cdot \mathrm{dm}^{-3}\right)$. Each plot was composed of pots with $7 \mathrm{dm}^{3}$ soil and five plants. Soil moisture was maintained by the gravimetric method at $60 \%$ of the maximum soil water retention capacity. Three harvests of the plant aerial part were performed at 30-day intervals. The evaluated characteristics were plant height, leaf number, tiller number, and chlorophyll index. Results were submitted to the variance analysis by $F$ test and, after verification of the significant effects on Marandu and Xaraes characteristics, were also submitted to Tukey test; the wood ash doses were evaluated according to the regression analysis at $5 \%$ probability. Wood ash doses ranging from 10.15 to $15 \mathrm{~g} \cdot \mathrm{dm}^{-3}$ resulted in quadratic responses of plant height, leaf number, and tiller number for both Marandu and Xaraes grasses. The highest values of chlorophyll index derived from wood ash doses of 9.44 and $10.92 \mathrm{~g} \cdot \mathrm{dm}^{-3}$, with increments greater than $50 \%, 25 \%$, and $9 \%$ at the first, second, and third harvests, respectively. The wood ash, when used as a fertilizer, improves structural characteristics and increases chlorophyll indices of Marandu and Xaraes grasses cultivated in Cerrado Rhodic Hapludox.

\section{Keywords}

Alternative Fertilizer, Brachiaria brizantha, Marandu, Xaraes

\footnotetext{
${ }^{*}$ Corresponding author.
} 


\section{Introduction}

The nutrient supply via fertilization is important for appropriate plant growth, development, and chlorophyll index. Forage grasses do require nutrients for pasture production and persistence. The resulting wood ash from boilers presents these nutrients and has been an alternative fertilizer for several crops, such as leafy vegetables like lettuce [1] and rocket [2], and grasses such as sorghum [3] and Marandu [4]-[6].

The agricultural application of solid wastes derived from agroindustrial processing has been a relevant disposal strategy since the use of this byproduct as a fertilizer has been an important tool for improvement of soil fertility, thus crop production. Therefore, when it is properly supplied, it may result in increases of pasture productivity and quality.

However, the technical knowledge on this residue management and limiting factors to production must be considered, as well as doses, soil classes, and nutrient requirements by crops [7]; when studying the effect of wood ash fertilization on Marandu grass cultivated in Cerrado Rhodic Hapludox, improvements are observed in its structural characteristics, such as height, leaf number, and tiller number that were promoted by the residue application.

Results of wood ash agricultural use as a soil corrective fertilizer indicated a significant increase in crop production [3]. Moreover, its use enables a reduction of fertilization costs since such residue is largely generated at agroindustrial centers for production of thermal energy.

These issues highlight the advantages of using this byproduct for fertilization and yield increase. The objective of this study was to evaluate the structural characteristics and chlorophyll index of Marandu and Xaraes grasses cultivated in Cerrado Rhodic Hapludox and fertilized with wood ash.

\section{Material and Methods}

The experiment was conducted in a greenhouse. The used soil, classified as Rhodic Hapludox [8], was collected at $0.00-0.20 \mathrm{~m}$ depth. Its chemical and granulometric characteristics are: $\mathrm{pH}\left(\mathrm{CaCl}_{2}\right)=4.0$; O.M. $=24.80$ $\mathrm{g} \cdot \mathrm{dm}^{-3} ; \mathrm{P}=1.2 \mathrm{mg} \cdot \mathrm{dm}^{-3} ; \mathrm{K}=40.0 \mathrm{mg} \cdot \mathrm{dm}^{-3} ; \mathrm{Ca}=0.2 \mathrm{cmol}_{\mathrm{c}} \cdot \mathrm{dm}^{-3} ; \mathrm{Mg}=0.1 \mathrm{cmol}_{\mathrm{c}} \cdot \mathrm{dm}^{-3} ; \mathrm{Al}=1.3 \mathrm{cmol}_{\mathrm{c}} \cdot \mathrm{dm}^{-3}$; $\mathrm{V}=6.5 \%$; sand $=476 \mathrm{~g} \cdot \mathrm{kg}^{-1}$; clay $=441 \mathrm{~g} \cdot \mathrm{kg}^{-1}$; and silt $=83 \mathrm{~g} \cdot \mathrm{kg}^{-1}$.

Characterized as a fertilizer by reference [9], the wood ash used in this study originated from boilers of the food industry. Its characteristics are: $\mathrm{pH}\left(\mathrm{CaCl}_{2}\right)=10.90 ; \mathrm{N}=0.56 \% ; \mathrm{P}_{2} \mathrm{O}_{5}$ [neutral ammonium citrate (NAC) + water $]=1.70 \% ; \mathrm{K}_{2} \mathrm{O}=2.72 \% ; \mathrm{Zn}=0.01 \% ; \mathrm{Cu}=0.01 \% ; \mathrm{Mn}(\mathrm{NAC}+$ water $)=0.00 \% ; \mathrm{B}=0.02 \% ; \mathrm{Ca}=2.70 \%$; and $\mathrm{S}=1.49 \%$.

The experimental design was entirely randomized, with 12 treatments and six replications arranged in a $2 \times 6$ factorial scheme, with two forage grasses (Marandu and Xaraes) and six wood ash doses $(0 ; 3 ; 6 ; 9 ; 12$; and 15 $\mathrm{g} \cdot \mathrm{dm}^{-3}$ ). Each plot was composed of pots with $7 \mathrm{dm}^{3}$ soil and five plants. Wood ash was incorporated into the soil and incubated for 30 days. Soil moisture was maintained according to the gravimetric method at $60 \%$ of the maximum soil water retention capacity.

After soil incubation with wood ash, the grasses were sowed using 20 seeds per pot. Thinning was performed when seedlings reached height of $10 \mathrm{~cm}$, remaining five plants per pot. Homogeneity and pot arrangement were also considered. After thinning, all experimental plots were fertilized with nitrogen $\left(200 \mathrm{mg} \cdot \mathrm{dm}^{-3}\right)$, using urea as the source. The same fertilization was performed at each harvest; the first was carried out at plant thinning, and the second and third, after each harvest.

At the first plant growth cycle, after thinning, fertilization with the micronutrients boron, copper, zinc, and molybdenum was performed, which doses and sources were, respectively, $1.39 \mathrm{mg} \cdot \mathrm{dm}^{-3}$ boric acid, 2.61 $\mathrm{mg} \cdot \mathrm{dm}^{-3}$ cuprous chloride, $2.03 \mathrm{mg} \cdot \mathrm{dm}^{-3}$ zinc chloride, and $0.36 \mathrm{mg} \cdot \mathrm{dm}^{-3}$ sodium molybdate.

Three harvests of the plant aerial part were performed at 30-day intervals. The first was carried out 30 days after plant emergence. For each harvest, evaluations of plant height, leaf number, tiller number, and chlorophyll index were performed for both Marandu and Xaraes grasses.

Plant height was measured with the aim of a ruler from soil surface to the forage sward curvature, resulting in a plant mean per pot. The SPAD (Soil Plant Analysis Development) index, that determines the chlorophyll index, was obtained using the portable chlorophyll meter Minolta SPAD-502. A number of 10 readings were performed per experimental unit, placed on newly expanded diagnostic leaves (leaves +1 and +2 ), when light intensity conditions were appropriate; leaf veins were disregarded. The mean of the SPAD readings per each pot was used. Counting of leaves and tillers were carried out at plant harvest. 
Results were submitted to the variance analysis by F test. After verification of the treatment significant effects on plant characteristics, data on the forage grasses were submitted to Tukey test, and on the wood ash doses, to the regression analysis, both at 5\% probability, using Sisvar statistical software [10].

\section{Results and Discussion}

There was interaction among forage grasses and wood ash doses for plant height, leaf number, and tiller number, for both Marandu and Xaraes grasses, at all evaluations, with the exception of plant height and tiller number at the second harvest (Table 1). Structural characteristics of both grasses were influenced; at the second harvest, higher leaf number was observed for Marandu grass, and greater plant height, for Xaraes (Table 2).

Plant height of Marandu and Xaraes grasses, according to the wood ash doses, indicates different nutritional requirements of same forage grass species in response to fertilization with this residue. It is important to mention that these differences may also be explained by Xaraes genetic characteristics, as it is an erect and taller plant. Possibly, these parameters were the most favorable factors that highlighted its height in comparison with Marandu [11]. We may also consider that Marandu grass presents a caespitose growth habit.

Regarding the wood ash doses, maximum heights of Marandu $(90.17 \mathrm{~cm})$ and Xaraes $(87.94 \mathrm{~cm})$ were observed, at the first harvest, for doses of 10.17 and $10.87 \mathrm{~g} \cdot \mathrm{dm}^{-3}$, respectively, amounting to increments of 69.69\% for Marandu and $65.18 \%$ for Xaraes (Figure 1(a)). At the second harvest, maximum plant height $(111.40 \mathrm{~cm})$ was promoted by the wood ash dose of $10.15 \mathrm{~g} \cdot \mathrm{dm}^{-3}$, with an increment of $53.68 \%$ (Figure 1(b)). At the third harvest, the greatest heights $(85.60$ and $99.14 \mathrm{~cm})$ were observed for the doses of 12.53 and 10.77 $\mathrm{g} \cdot \mathrm{dm}^{-3}$, respectively, resulting in $35.79 \%$ increase for Marandu and $52.92 \%$ for Xaraes (Figure 1(c)).

Table 1. Interactions among forage grasses and wood ash doses for structural characteristics and chlorophyll index of Marandu and Xaraes grasses.

\begin{tabular}{|c|c|c|c|c|c|}
\hline \multirow{2}{*}{ Characteristics } & \multicolumn{3}{|c|}{ Variation source } & \multirow{2}{*}{ Harvests } & \multirow{2}{*}{$\begin{array}{c}\text { Coefficient } \\
\text { of variation }(\%\end{array}$} \\
\hline & Forage grass & Wood ash & Interaction & & \\
\hline \multirow[t]{3}{*}{ Plant height $(\mathrm{cm})$} & $0.8732^{\mathrm{ns}}$ & $0.0000^{* * *}$ & $0.0212^{*}$ & $1^{\mathrm{st}}$ & 7.90 \\
\hline & $0.0000^{* * *}$ & $0.0000^{* * *}$ & $0.4564^{\mathrm{ns}}$ & $2^{\text {nd }}$ & 10.75 \\
\hline & $0.0001^{* *}$ & $0.0000^{* * *}$ & $0.0000^{* * *}$ & $3^{\text {rd }}$ & 9.49 \\
\hline \multirow[t]{3}{*}{ Leaves (number.pot ${ }^{-1}$ ) } & $0.0000^{* * * *}$ & $0.0000^{* * *}$ & $0.0000^{* * *}$ & $1^{\mathrm{st}}$ & 11.39 \\
\hline & $0.0000^{* * * *}$ & $0.0000^{* * *}$ & $0.0000^{* * *}$ & $2^{\text {nd }}$ & 13.62 \\
\hline & $0.0000^{* * *}$ & $0.0000^{* * *}$ & $0.0003^{* *}$ & $3^{\text {rd }}$ & 15.33 \\
\hline \multirow[t]{3}{*}{ Tillers (number·pot ${ }^{-1}$ ) } & $0.0008^{* *}$ & $0.0000^{* * *}$ & $0.0157^{*}$ & $1^{\mathrm{st}}$ & 12.01 \\
\hline & $0.0651^{\mathrm{ns}}$ & $0.0000^{* * *}$ & $0.2518^{\mathrm{ns}}$ & $2^{\text {nd }}$ & 15.85 \\
\hline & $0.0000^{* * *}$ & $0.0000^{* * *}$ & $0.0000^{* * *}$ & $3^{\text {rd }}$ & 11.51 \\
\hline Chlorophyll index & $0.7446^{\mathrm{ns}}$ & $0.0000^{* * *}$ & $0.0007^{* *}$ & $1^{\text {st }}$ & 6.73 \\
\hline \multirow[t]{2}{*}{ (SPAD) } & $0.3686^{\mathrm{ns}}$ & $0.000{ }^{* * *}$ & $0.0848^{\mathrm{ns}}$ & $2^{\text {nd }}$ & 7.12 \\
\hline & $0.0001^{* *}$ & $0.0000^{* * * *}$ & $0.0000^{* * * *}$ & $3^{\text {rd }}$ & 9.49 \\
\hline
\end{tabular}

${ }^{\mathrm{ns}}$ Non-significant by F test at $5 \%$ probability. ${ }^{* * *} ;{ }^{* *} ;{ }^{*}$ Significant at $0.1 \%$; $1 \%$; and $5 \%$ probability, respectively.

Table 2. Plant height of Marandu and Xaraes grasses at the second evaluation harvest.

\begin{tabular}{cc}
\hline Forage Grass & Plant Height (cm) Second Harvest \\
\hline Marandu & $86.51 \mathrm{~b}$ \\
Xaraes & $97.67 \mathrm{a}$ \\
CV\% & 10.75 \\
\hline
\end{tabular}

Means followed by different letters in the column differ from each other by the Tukey test at 5\% probability. 


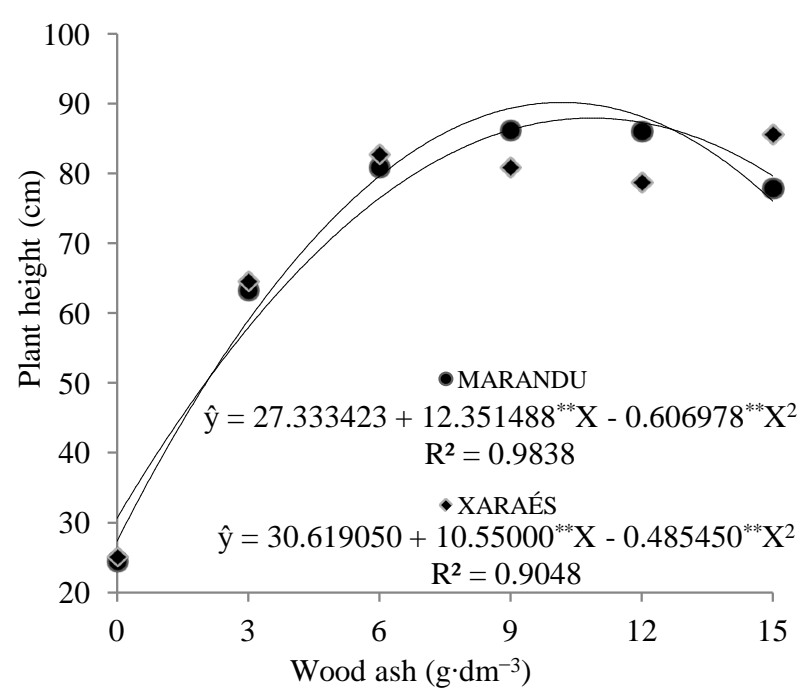

(a)

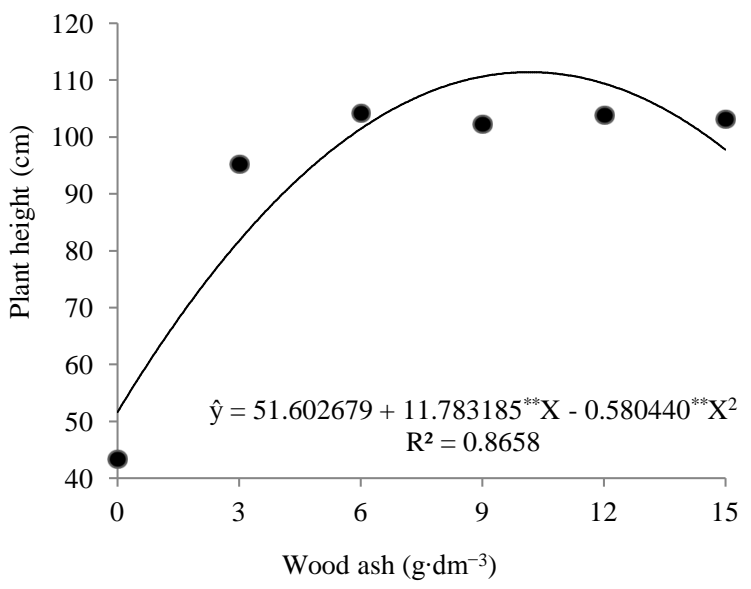

(b)

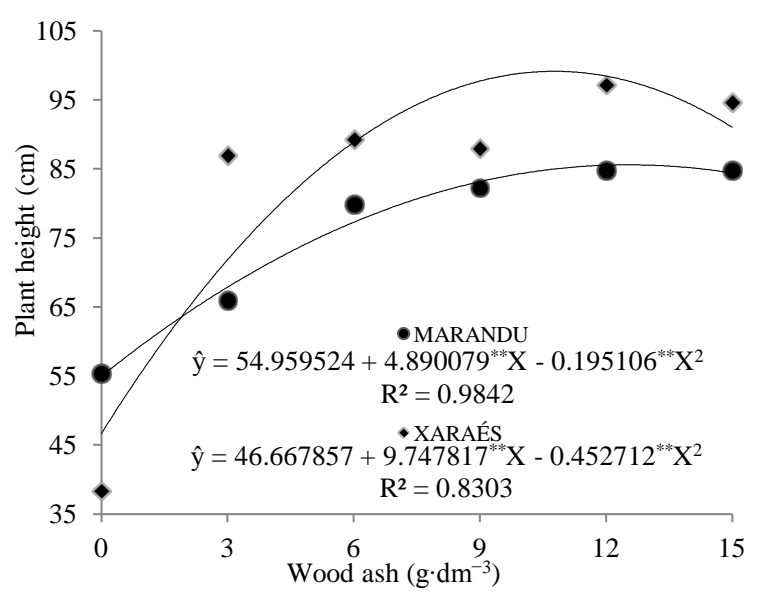

(c)

Figure 1. Plant height of Marandu and Xaraes grasses according to wood ash doses at the first (a); second (b); and third (c) harvests. ${ }^{* *}$ Significant at $1 \%$ probability.

The determination of plant height, among others, is an important characteristic for evaluation of the productive potential of forage grasses [12]. Furthermore, according to reference [13], it is a relevant structural characteristic also for an appropriate management.

Considering the mean satisfactory heights for forage production [14] and significant increments, with a possible cost reduction in pasture management because of wood ash use as a grass fertilizer [7], we also observed that the treatment with the lowest wood ash dose $\left(3 \mathrm{~g} \cdot \mathrm{dm}^{-3}\right)$ promoted a superior plant height to $50 \mathrm{~cm}$ (Figures 1(a)-(c)).

Such occurrence may be possibly attributed to the residual effect of the wood ash fertilization, emphasizing that there was no further application at the second and third harvests. Therefore, such fertilization residual effect probably improved soil fertility conditions, promoting greater heights of both Marandu and Xaraes grasses.

At the first harvest, the greatest wood ash dose promoted an increase in Marandu leaf number of 78.67\% when compared with the treatment that did not have the residue application. The greatest leaf production (124.55 leaves) by Xaraes grass was observed when it was submitted to the wood ash dose of $13.77 \mathrm{~g} \cdot \mathrm{dm}^{-3}$, resulting in $83.27 \%$ increase (Figure 2(a)).

The greatest leaf number of Marandu (245.84) and Xaraes (190.41) at the second harvest derived from the wood ash doses of, respectively, 14.25 and $12.75 \mathrm{~g} \cdot \mathrm{dm}^{-3}$. Maximum leaf production resulted in increases of $89.85 \%$ for Marandu and $85.84 \%$ for Xaraes grasses (Figure 2(b)). 


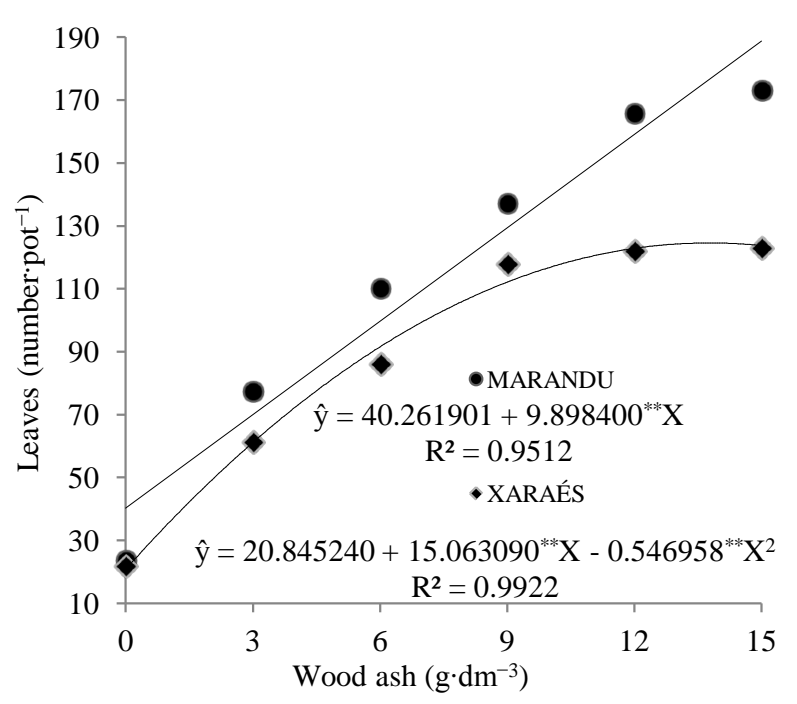

(a)

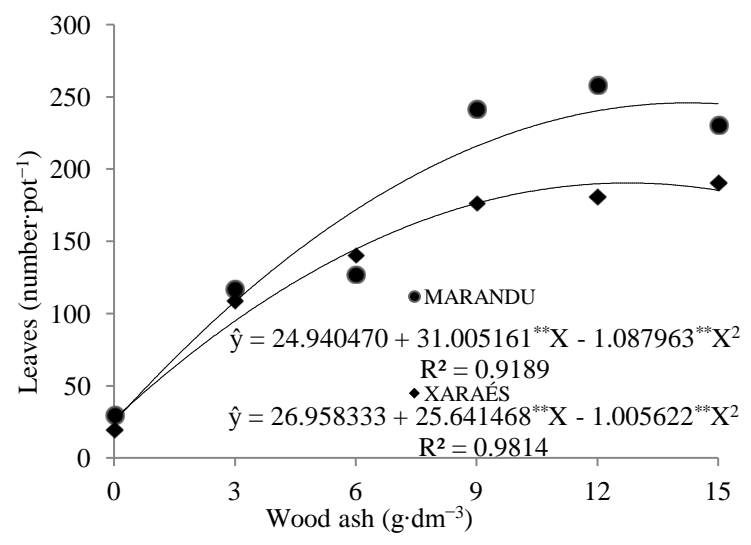

(b)

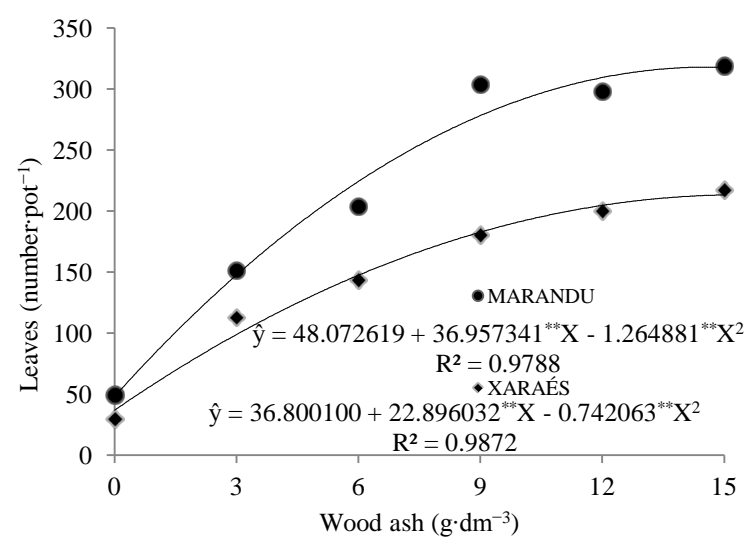

(c)

Figure 2. Leaf number of Marandu and Xaraes grasses according to wood ash doses at the first (a); second (b); and third (c) harvests. ${ }^{* *}$ Significant at $1 \%$ probability.

At the third harvest, the wood ash doses that promoted greatest leaf production (318.03 leaves for Marandu, and 213.41 for Xaraes) were 14.61 and $15.00 \mathrm{~g} \cdot \mathrm{dm}^{-3}$, respectively, with increments of $84.88 \%$ for Marandu and 82.76\% for Xaraes (Figure 2(c)).

Significant increases of 47.58 and $39.56 \%$ in Marandu leaf number, evaluated along two growth cycles, respectively, were observed by reference [2], who studied wood ash application effects, with doses that ranged from 0 to $3.75 \mathrm{~g} \cdot \mathrm{dm}^{-3}$, and reapplications at each harvest. These increments are positive, once leaf number is a characteristic that enables leaf area renovation of forage grasses, aiming at the maintenance of grass production and perpetuation [15]. These aspects are also important when management is considered, as the formation of new leaves is an essential process for species survival as well as a substantial evaluation parameter of efficient soil coverage.

Regarding tiller number, greater production (43.13 and 37.97 tillers pot $^{-1}$ ) was observed, at the first harvest, for the wood ash doses of 12.85 and $11.08 \mathrm{~g} \cdot \mathrm{dm}^{-3}$, respectively, resulting in 92.98\% increase for Marandu, and 91.04\% for Xaraes (Figure 3(a)). At the second harvest, maximum tiller production (53.94 tillers pot $^{-1}$ ) was promoted by the greatest wood ash dose of the experimental interval $\left(15 \mathrm{~g} \cdot \mathrm{dm}^{-3}\right)$, with $86.10 \%$ increment (Figure 3(b)). At the third harvest, there were increases of 78.60 and $76.00 \%$ for Marandu and Xaraes grasses, respectively (Figure 3(c)).

Tiller number is, therefore, an indicative of grass vigor and persistence in pastures. The prominence of plant tiller formation is the main factor determining production; it directly depends on the plant growth stage [16]. 


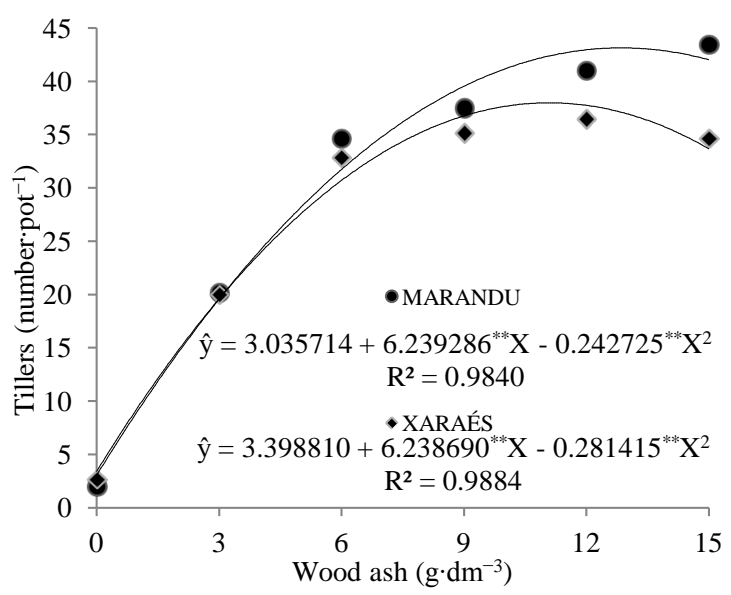

(a)

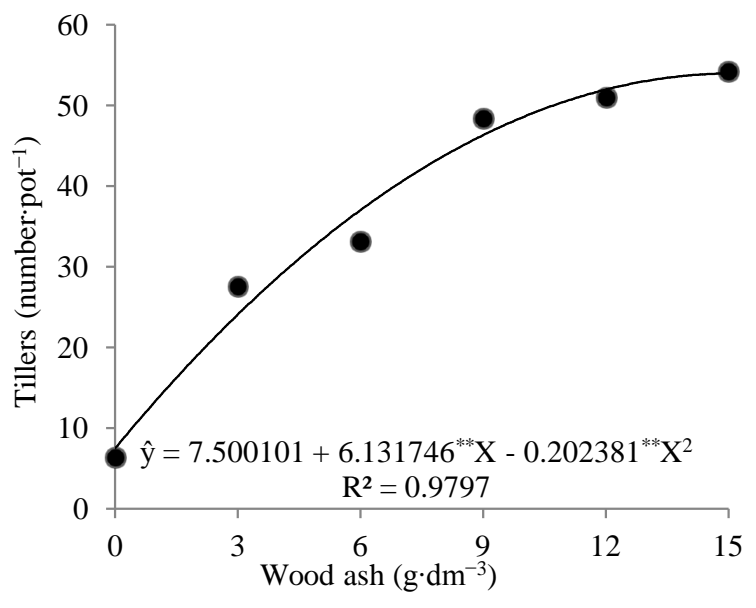

(b)

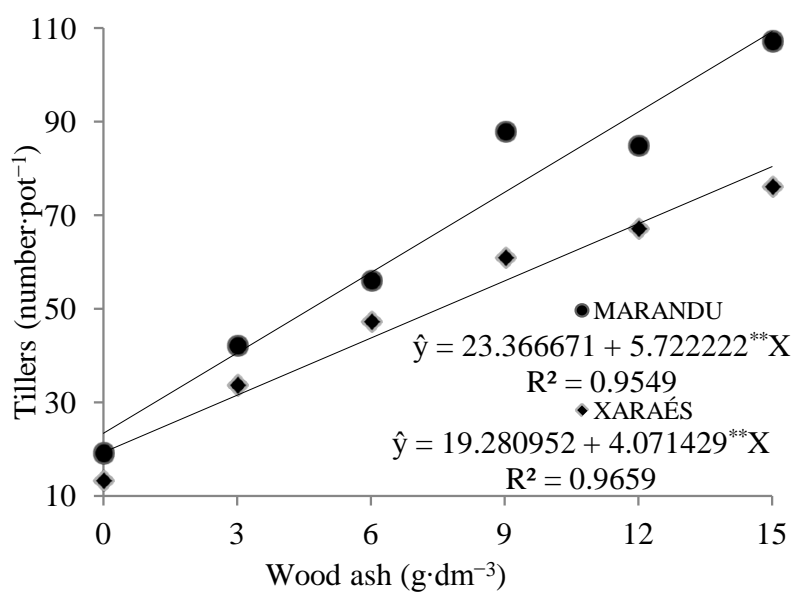

(c)

Figure 3. Tiller number of Marandu and Xaraes grasses according to wood ash doses at the first (a); second (b); and third (c) harvests. ${ }^{* *}$ Significant at $1 \%$ probability.

Fertilization with wood ash did influence maximum tiller production of both Marandu and Xaraes grasses at the first and second harvests, contributing to more grass vigor and persistence; thus, our results validate the use of this residue to improve grass tillering and pasture perpetuation.

At all harvests, however, the use of wood ash as a fertilizer presented significant results of tiller production for both Marandu and Xaraes grasses. Therefore, it is necessary to emphasize that tiller production is a very important structural characteristic and serve as an indicative parameter of forage grass growth.

There was a significant interaction for chlorophyll index among forage grasses and wood ash doses only at the first harvest. At the second and third, the observed chlorophyll index means were 48.16 and 48.38 for Marandu grass, respectively, and 47.54 and 47.01 for Xaraes. We observed, however, that the chlorophyll indices at these harvests corroborated those (>50) obtained for Brachiaria brizantha by references [17] [18].

In this study, at all harvests, results of chlorophyll index for both Marandu and Xaraes grasses were adjusted to a quadratic regression model.

At the first one, there was interaction among forage grasses and wood ash doses, with highest chlorophyll indices (53.57 for Marandu, and 56.28 for Xaraes) promoted by the wood ash doses of 10.77 and $10.92 \mathrm{~g} \cdot \mathrm{dm}^{-3}$, respectively, with increments of 55.03\% for Marandu and 68.86\% for Xaraes when compared with the treatment that did not have any wood ash application (Figure 4(a)). At the second, there was an isolated effect among factors; the wood ash dose of $9.44 \mathrm{~g} \cdot \mathrm{dm}^{-3}$ promoted the highest chlorophyll index (52.39) for both grasses, with 25.46\% increase (Figure 4(b)). And at the third harvest, the $9.65 \mathrm{~g} \mathrm{dm}^{-3}$ dose promoted the highest chlorophyll index (49.13) for both grasses (Figure 4(c)). 


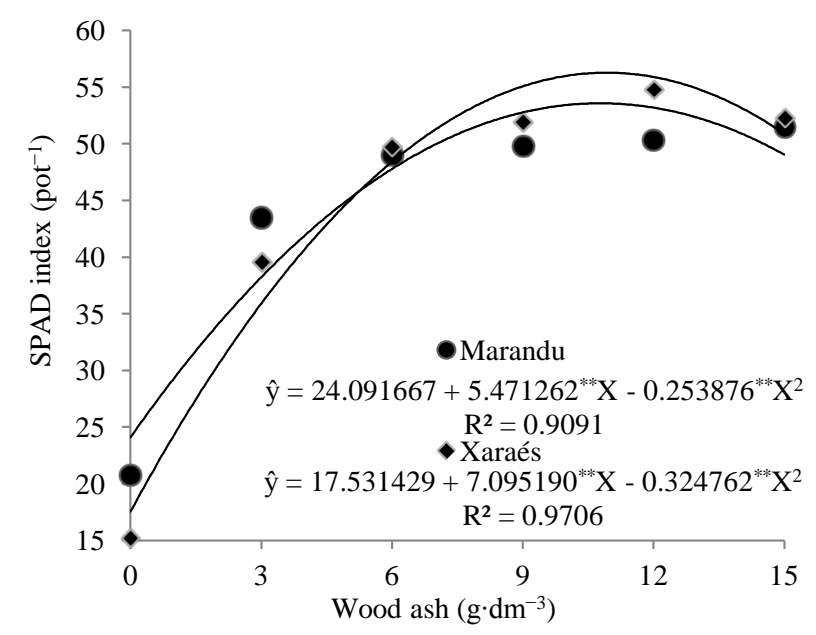

(a)

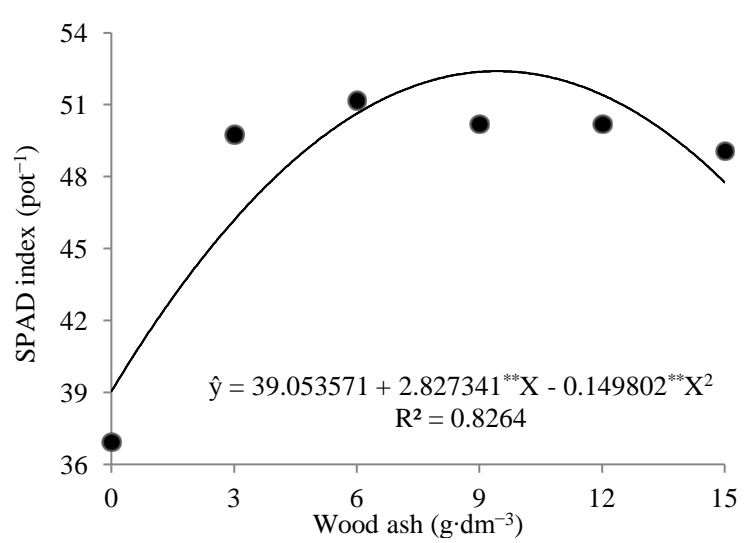

(b)

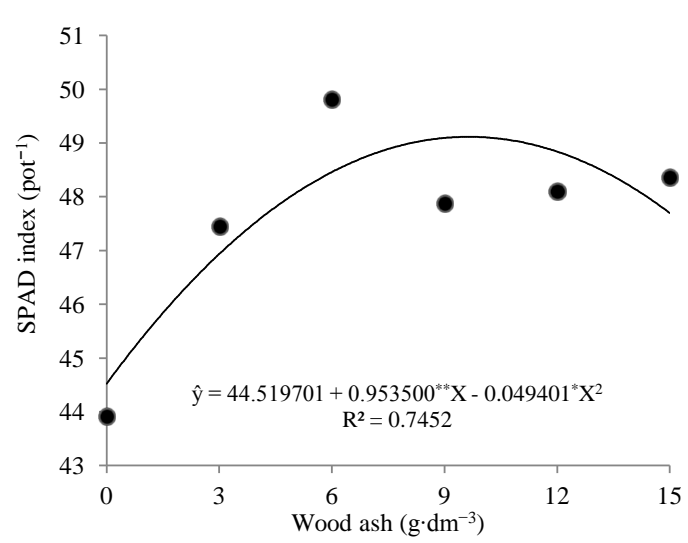

(c)

Figure 4. Chlorophyll index for Marandu and Xaraes grasses according to wood ash doses at the first (a); second (b); and third (c) harvests. ${ }^{* *}$; Significant at $1 \%$; and $5 \%$ probability, respectively.

The chlorophyll index of Marandu and Xaraes leaves, as a result of wood ash application, shows the importance of this residue as a nutrient supplier to forage plants since significant leaf production increments (above 85\%) were observed in this study.

Reference [18], when studying the nitrogen nutritional diagnosis of Aruana grass cultivated under controlled conditions, observed a quadratic response of chlorophyll indices of 52.6 at the first growth cycle. Reference [17], when working with Marandu grass cultivated in a nutrient solution, also observed a quadratic response of the chlorophyll index, achieving 54.03 at 35 days of growth. In this study, chlorophyll indices observed at both first and second harvests corroborate those found by reference [17] [18].

\section{Conclusions}

The wood ash, used as a fertilizer, improves structural characteristics and chlorophyll indices of Marandu and Xaraes grasses cultivated in Cerrado Rhodic Hapludox.

Marandu and Xaraes grasses reached maximum productions and chlorophyll indices at three harvests; the exception was leaf number of Marandu grass, which was adjusted to a linear regression model.

\section{References}

[1] Darolt, M.R., Blanco Neto, V. and Zambon, F.R.A. (1993) Cinza vegetal como fonte de nutrientes e corretivo de solo na cultura de alface. Horticultura Brasileira, 11, 38-40. http://www.iapar.br/arquivos/File/zip_pdf/darolt_cinzavegetal.pdf 
[2] Bonfim-Silva, E.M., Silva, T.J.A., Santos, C.C., Cabral, C.E.A. and Santos, I.B. (2011) Características produtivas e eficiência no uso de água em rúcula adubada com cinza vegetal. Enciclopédia Biosfera, 7, 178-186. http://www.conhecer.org.br/enciclop/2011b/ciencias\%20agrarias/caracteristicas\%20produtivas.pdf

[3] Almeida, F.A.G., Fontes, J.M. and Almeida, F.C.G. (1988) Uso da Cinza da Casca de Castanha do Caju como Fonte Fósforo para Cultura do Sorgo (Sorghum bicolor (L.) Moench.). Ciências Agronômicas, 19, 67-72.

[4] Bonfim-Silva, E.M., Cabral, C.E.A., Silva, T.J.A., Moreira, J.C.F. and Carvalho, J.C.S. (2013) Cinza vegetal: Características produtivas e índice de clorofila do capim-marandu. Bioscience Journal, 29, 1915-1225. http://www.seer.ufu.br/index.php/biosciencejournal/article/view/15073/13015

[5] Bonfim-Silva, E.M., Santos, C.C., da Silva, T.J.A. and Scaramuzza, W.L.M.P. (2014) Concentration of Nitrogen, Phosphorus and Potassium in Tropical Grasses Fertilised with Wood Ash in Cerrado Oxisol. African Journal of Agricultural Research, 9, 549-555. http://dx.doi.org/10.5897/AJAR2013.8278

[6] Santos, C.C., Bonfim-Silva, E.M. and Silva, T.J.A. (2014) Tropical Grass Fertilized with Wood Ash in Cerrado Oxisol: Concentrations of Calcium, Magnesium and Sulphur. African Journal of Agricultural Research, 9, 1495-1501. http://dx.doi.org/10.5897/AJAR2014.8635

[7] Bonfim-Silva, E.M., Silva, T.J.A., Cabral, C.E.A., Valadares, E.M. and Goldoni, G. (2011) Características morfológicas e estruturais de capim-marandu adubado com cinza vegetal em Latossolo Vermelho do Cerrado Enciclopédia Biosfera, 7, 1-9. http://www.conhecer.org.br/enciclop/2011a/agrarias/caracteristicas\%20morfologicas.pdf

[8] Embrapa-Empresa Brasileira de Pesquisa Agropecuária (1997) Manual de métodos de análises de solo. Centro Nacional de Levantamento e Conservação do Solo, Rio de Janeiro.

[9] Osaki, F. and Darolt, M.R. (1991) Estudo da qualidade de cinzas vegetais para uso como adubos na região metropolitana de Curitiba. Revista Setor Ciências Agrárias, 11, 197-205. http://www.iapar.br/arquivos/File/zip_pdf/darolt_qualcinzasv.pdf

[10] Ferreira, D.F. (2008) SISVAR: Um programa para análises e ensino estatístico. Revista Symposium, 3, 317-345.

[11] Silveira, M.C.T. (2006) Caracterização morfogênica de oito cultivares do gênero Brachiaria e dois do gênero Panicum. Dissertação (Mestrado em Zootecnia), Universidade Federal de Viçosa, Viçosa, 91 p. http://alexandria.cpd.ufv.br:8000/teses/zootecnia/2006/200449f.pdf

[12] Canto, M.W., Cecato, U., Peternelli, M., Jobim, C.C., Júnior, J.A., Rigolon, L.P., Watfe, E., Barrionuevo, C.V. and Nunes, B.R.C. (2001) Sward Characteristics of Deferred Tanzania Grass under Different Height Levels, in the Winter Time. Revista Brasileira de Zootecnia, 30, 1186-1193. http://dx.doi.org/10.1590/S1516-35982001000500008

[13] Hernández, G.A., Matthew, C. and Hodgson, J. (1997) Effect of Spring Grazing Management on Perennial Ryegrass and Ryegrass-White Clover Pastures 2. Tiller and Growing Point Densities and Population Dynamics. New Zealand Journal of Agricultural Research, 40, 37-50. http://dx.doi.org/10.1080/00288233.1997.9513228

[14] Sbrissia, A.F. (2004) Morfogênese, dinâmica do perfilhamento e do acúmulo de forragem em pastos de capim-marandu sob lotação contínua. Tese (Doutorado em Agronomia), Escola Superior de Agricultura "Luiz de Queiroz", Piracicaba, 171 p. http://www.teses.usp.br/teses/disponiveis/11/11139/tde-25052004-143513/pt-br.php

[15] Cunha, F.F., Ramos, M.M., Alencar, C.A.B., Oliveira, R.A., Araújo, R.A.S., Cecon, P.R., Martins, C.E. and Cóser, A.C. (2011) Número de folhas do capim-xaraés em diferentes manejos e doses de adubação, intervalos de desfolha e estações Anuais. Bioscience Journal, 27, 271-282. http://www.seer.ufu.br/index.php/biosciencejournal/article/view/7352/7233

[16] Silsbury, J.H. (1966) Interrelations in the Growth and Development of Lolium. II. Tiller Number and Dry Weight at Low Density. Australian Journal Research, 17, 841-847. http://dx.doi.org/10.1071/AR9660841

[17] Santos Junior, J.D.G. (2001) Dinâmica e de crescimento do capim-marandu submetido a doses de nitrogênio. Dissertação (Mestrado em Agronomia), Escola Superior de agricultura Luiz de Queiroz, Ciência do Solo, Universidade de São Paulo, Piracicaba. http://www.teses.usp.br/teses/disponiveis/11/11140/tde-19032002-164549/pt-br.php

[18] Junior, J.L. and Monteiro, F.A. (2006) Nitrogen Nutritional Status in Aruana Grass in a Controlled Environment. Revista Brasileira de Ciência do Solo, 30, 829-837. http://dx.doi.org/10.1590/S0100-06832006000500009 